\title{
A Syndrome of Brain, Inner Ear and Retinal Microangiopathy
}

\author{
D.J. MacFadyen, R.J. Schneider, I.A. Chisholm
}

\begin{abstract}
We report the seventh case of a self-limiting syndrome of brain, inner ear and retinal microangiopathy which affects adult women producing mild to moderate mental status and personality changes, mild pyramidal and cerebellar dysfunction, patchy and asymmetrical visual loss secondary to non-inflammatory retinal infarctions, and asymmetrical neurosensory hearing loss. There is no clinical or laboratory evidence of involvement beyond the brain, the eyes and the ears. Magnetic resonance imaging or brain biopsy in previously reported cases best outline the brain pathology: multiple microinfarcts. All cases have been treated with steroids or cyclophosphamide. The etiology is unknown but may be related to systemic lupus erythematosus.
\end{abstract}

RÉSUMÉ: Micro-angiopathies localisées au cerveau, à l'oreille interne et à la rétine. Nous rapportons le septième cas d'un syndrome comportant des micro-angiopathies à localisation bien circonscrite, soit au niveau du cerveau, de l'oreille interne et de la rétine. Ce syndrome atteignant les femmes d'âge adulte, provoque une altération de légère à modérée de l'état mental, des modifications de la personnalité, une légère dysfonction pyramidale et cérébelleuse, une perte de vision en plaques disséminées et asymétrique qui est secondaire à des infarcissements rétiniens non-inflammatoires et une surdité neurosensorielle asymétrique. Aucune atteinte autre qu'au cerveau, aux yeux et aux oreilles ne peut être mise en évidence par la clinique ou les examens de laboratoire. L’imagerie par résonance magnétique ou la biopsie cérébrale sont les deux examens qui démontrent le mieux la pathologie cérébrale sousjacente à cette entité, soit les nombreux micro-infarctus. Tous les cas ont été traités au moyen de stéroïdes ou de cyclophosphamide. L'étiologie de ce syndrome est inconnue, mais elle pourrait être reliée au lupus érythémateux aigu disséminé.

Can. J. Neurol. Sci. 1987; 14:315-318

To date six patients, all young women, have been described with a remarkably similar and distinctive syndrome of retinal arteriolar infarction, neurosensory hearing loss especially in the lower frequencies (presumably due to infarction of the cochlear apex), and small multifocal central nervous system white and grey matter infarcts. The course of the disease seems to be biphasic or multiphasic with a duration of several months followed by partial recovery and a lengthy remission. The first two cases were described in 1979 by Susac et al. ' Two cases were reported by Coppeto et $\mathrm{al}^{2}$ in 1984 and two by Monteiro et $\mathrm{al}^{3}$ in 1985. The following case is another example of this syndrome.

\section{Case Report}

A 31 year old pregnant woman (para III, gravida IV) developed intermittent numbness of all four extremities in March 1981 followed by slurring of speech. In late April she noted a persistent "blind spot" in the left eye. Her corrected visual acuity was $20 / 20$. She had an exophoria on near vision and an area of left retinal infarction just superior to the macula within the area of supply of a cilioretinal artery. Goldman perimetry revealed two dense scotomas both at about $20^{\circ}$ of nasal eccentricity - one above and one below the horizontal meridian. One week later she developed horizontal diplopia and was found to have a left sixth nerve palsy confirmed on a Hess test.

In mid May she complained of lethargy, general malaise, unsteadiness of gait and had become noticeably less animated in her personality and less proficient in memory. She noted right ear tinnitus and a localized skin eruption on the right cheek. Her blood pressure was $95 / 65$. There was a one inch diameter erythematous papulo-vesicular skin eruption on the right lower cheek. She was alert, oriented, dysarthric, flat in affect and frequently referred to her husband for confirmation of her answers, but had no defect in memory and no dysphasia. The left optic disc was pale; the peripheral visual fields were intact and visual acuity was 20/20. Extra ocular movements were full, the abducens palsy having disappeared, and there was no nystagmus. The remainder of the cranial nerves were intact with normal Rinné and Weber tests. Muscle power, coordination and fine movements in the upper limbs were normal. There was a spastic catch upon elbow flexion bilaterally. Ordinary gait was normal but heel-toe walking and heel-knee testing were ataxic. Deep and superficial sensations were intact. Upper limb tendon reflexes were normal. The knee jerks were hyperactive with a Babinski reflex bilaterally and the abdominal reflexes were absent. The infarction edema in the left retina had subsided.

The patient's speech, memory, affect and ataxia improved without specific treatment but bilateral tinnitus developed and a bilateral low frequency neurosensory hearing loss, left greater than right (40 to 10 decibels threshold from $250-8000 \mathrm{~Hz}$ ), was detected. In November 1981

From the Departments of Clinical Neurological Sciences (Dr. MacFadyen) and Ophthalmology (Drs. Schneider and Chisholm), University Hospital. Saskatoon Received October 14, 1986. Accepted in final form March 31, 1987

Reprint requests to: Dr. D.J. MacFadyen, Department of Clinical Neurological Sciences, University Hospital, Saskatoon, Saskatchewan, Canada S7N 0X0 
she delivered a normal baby without complications but fatigue, dysarthria, incoordination in writing and gait and difficulty with memory reappeared. Her left hearing suddenly deteriorated (Figure 1).

In January 1982 because of persistent symptoms she was again admitted. Her physical signs and laboratory findings were unchanged. It was concluded that she was suffering from a type of vasculitis and she was started on prednisone, initially $60 \mathrm{mg} / \mathrm{day}$. Her speech, memory and "dizziness" improved.

She noted a further left visual loss in March 1982 following which her V.A. was $20 / 20 \mathrm{o}$.d. and $20 / 400 \mathrm{o}$.s., with correction. There were four small intraretinal hemorrhages and marked adjacent artery narrowing in the left retina with a retinal infarct below the left macula. Perivascular sheathing and artery narrowing were also present in the right retina. Visual fields (Goldman) showed a central scotoma and a quadrantic left superior nasal depression. There was a peripheral infero-temporal defect in the right visual field and a left afferent pupil defect. Prednisone was increased to $30 \mathrm{mg}$ per day. By August $1982 \mathrm{her}$ vision had improved to 20/20 (with correction) but a left paracentral scotoma remained. Her prednisone was slowly reduced and then stopped.

In November 1985 pure tone audiometry was abnormal bilaterally but slightly improved in the right ear over her previous maximum deficit (Figure 1). 100-Hue color vision testing revealed abnormal scores bilaterally: $R=197, L=320$ (normal score for age (a' $p=0.01=154)^{4}$. When last seen in January 1987 , nearly six years after the onset of her illness, she was on no medication and was feeling well except for fatigue, slurring of speech, some short term memory difficulty, and diminished hearing, left greater than right. V.A. was 20/20 with correction. Octopus perimetry (Program Gl) showed a patchy diffuse loss of retinal sensitivity bilaterally with a left paracentral scotoma. Neurological examination was normal except for clumsiness in hopping, hyperac- tive knee and right ankle reflexes and an equivocal left plantar reflex. Laboratory studies are as summarized in Table 1.

\section{Discussion}

The salient features of the six previously reported cases and this case are remarkably similar (Table 2). All are female, age 21-40, in whom the disease usually begins with personality or mental status changes including flattening of affect, memory loss, dementia, paranoia, obtundation. Simultaneously or very soon after the onset the other cardinal features appear, namely asymmetrical neurosensory hearing loss most marked in the low and middle frequencies, asymmetrical visual loss secondary to multiple retinal artery branch occlusions, and infarctions and relatively mild symptoms and signs of motor and cerebellar dysfunction. After a subacute course over a period of several months and sometimes with a biphasic course, there is a remission, with no subsequent exacerbation, leaving a residual mild to moderate mental status change and asymmetric hearing loss and visual changes. Extensive laboratory investigation to detect abnormalities beyond the eye, ear and brain is unrewarding, confirming the specificity of the pathology to the brain and these special sense organs. Consistent nervous system abnormalities include diffuse theta and delta activity on the EEG and an elevated CSF protein occasionally with a slight CSF

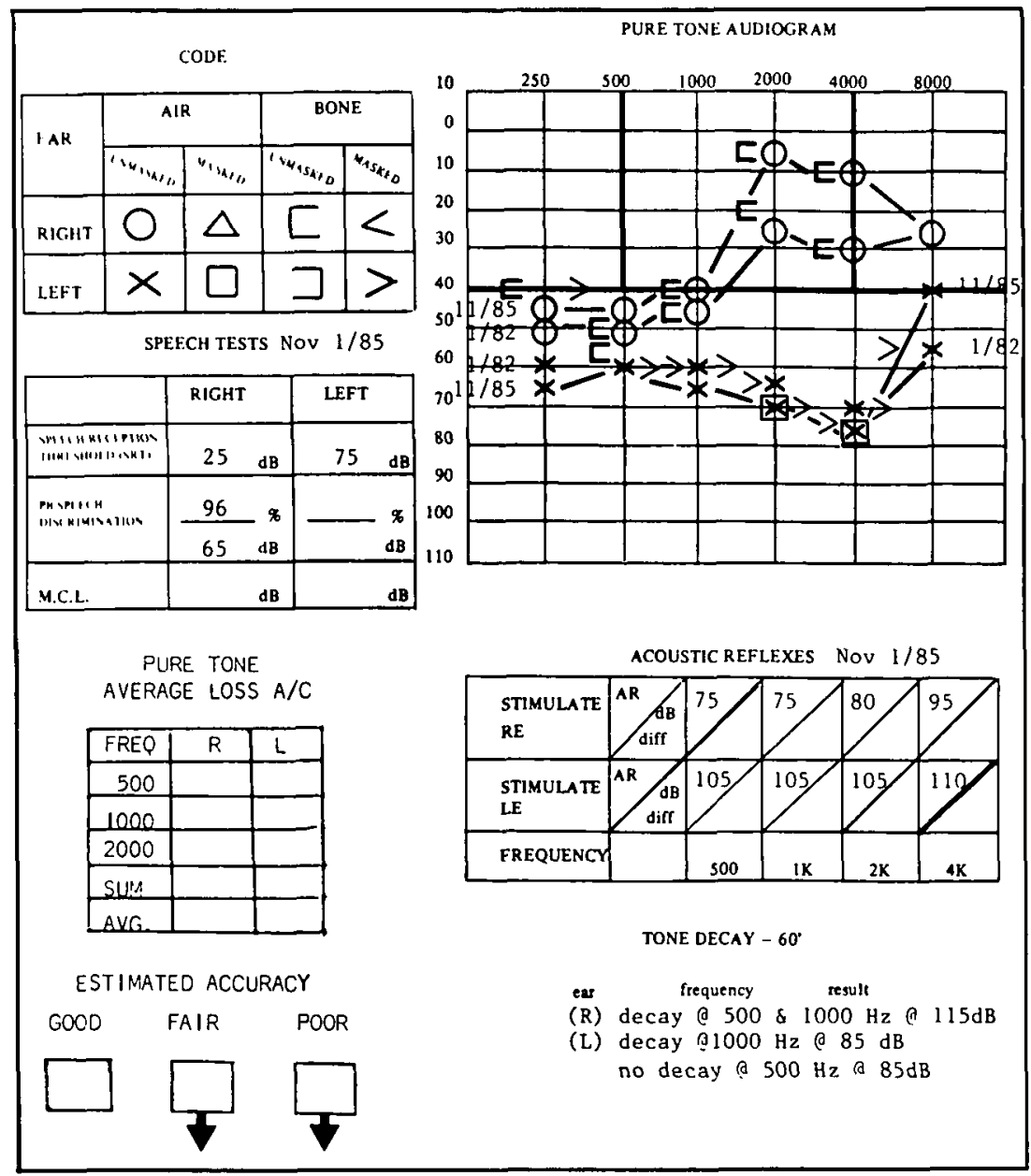

Figure I - Pure tone audiogram of January/82 and November/85 which illustrate the low frequency hearing loss and modest improvement between the two tests. Speech tests and acoustic reflexes of November/85 are also shown. 
lymphocytosis. Two patients have undergone a brain biopsy. In one "sclerosis of the media and adventitia of small pial and cortical vessels" consistent with a "healed angiitis" was found,' and in the other there were "numerous microinfarcts throughout the gray matter" with "no evidence of inflammation" or "fibrinoid necrosis of vessel walls". ${ }^{3}$ CT scanning of the brain reveals no abnormalities and, at most, cerebral angiography has revealed questionable "small vessel abnormalities".' Magnetic resonance imaging (MRI) of the brain in one patient ${ }^{3}$ showed "several high intensity foci - only in the white matter - compatible with small brain infarcts."

It seems clear from the ophthalmological findings that the visual abnormalities are the result of an arterial angiopathy which is not inflammatory, atherosclerotic nor likely embolic in nature. The brain biopsy and MRI findings outlined above are consistent with the ophthalmological findings. The inner ear pathology is unknown but is consistent with infarction of the cochlear apex, thus accounting for the predominantly low and middle frequency neurosensory hearing loss.

All patients were treated with corticosteroids or ACTH and three with cyclophosphamide. The effectiveness of this treatment is unclear as some patients had transient clinical improvement prior to the institution of therapy and all patients recovered partially from their initial central nervous system, visual and auditory symptoms.

The differential diagnosis has been extensively discussed in the three previous reports ${ }^{1.2 .3}$ and includes polyarteritis nodosa, allergic vasculitis, giant cell granulomatous angiitis of the nervous system, atypical Cogan's syndrome and systemic lupus erythematosus (SLE). The neurologic and retinal findings in these seven cases are not characteristic of even atypical Cogan's syndrome ${ }^{3}$ and therefore only SLE seems a serious consideration. Laboratory support for the diagnosis of SLE in these patients is lacking and our patient had only one of the 11 criteria used in the diagnosis of SLE, ${ }^{7}$ namely "neurologic disorder". Nevertheless, that these cases may represent a sero-negative "cerebral" type of SLE remains a possibility. Coppeto et $\mathrm{al}^{2}$ described their two cases as a "syndrome of arterial occlusive retinopathy and encephalopathy", did not elaborate upon the hearing loss in their two patients and included, as further examples of this syndrome, two patients without hearing loss described by Pfaffenbach and Hollenhorst ${ }^{5}$ and considered by them to be examples of probable SLE. Montero et $\mathrm{al}^{3}$ who emphasized the hearing loss in their two cases and in the previous four cases, "suspected" that the two patients of Pfaffenbach and Hollenhorst had "partial" manifestations of (this) microangiopathic syndrome" and similarly categorized a single patient described by Weidhauer and Tenner ${ }^{6}$ in which a young woman had bilateral neurosensory hearing loss, retinal artery branch occlusions but no central nervous system or systemic involvement.

This microangiopathic syndrome of arteries which appears to be unrelated to emboli, vasculitis or SLE might be related to a defect in coagulation such as occurs in the presence of lupus anticoagulant where thrombosis exceeds bleeding. Furthermore, lupus anticoagulant occurs more often in those without SLE than in those with it. ${ }^{8}$ Thus a search for a coagulation abnormality during the acute stage of this syndrome might help to clarify the etiology.

\section{Table 1: Results of laboratory investigations during "acute" stage}

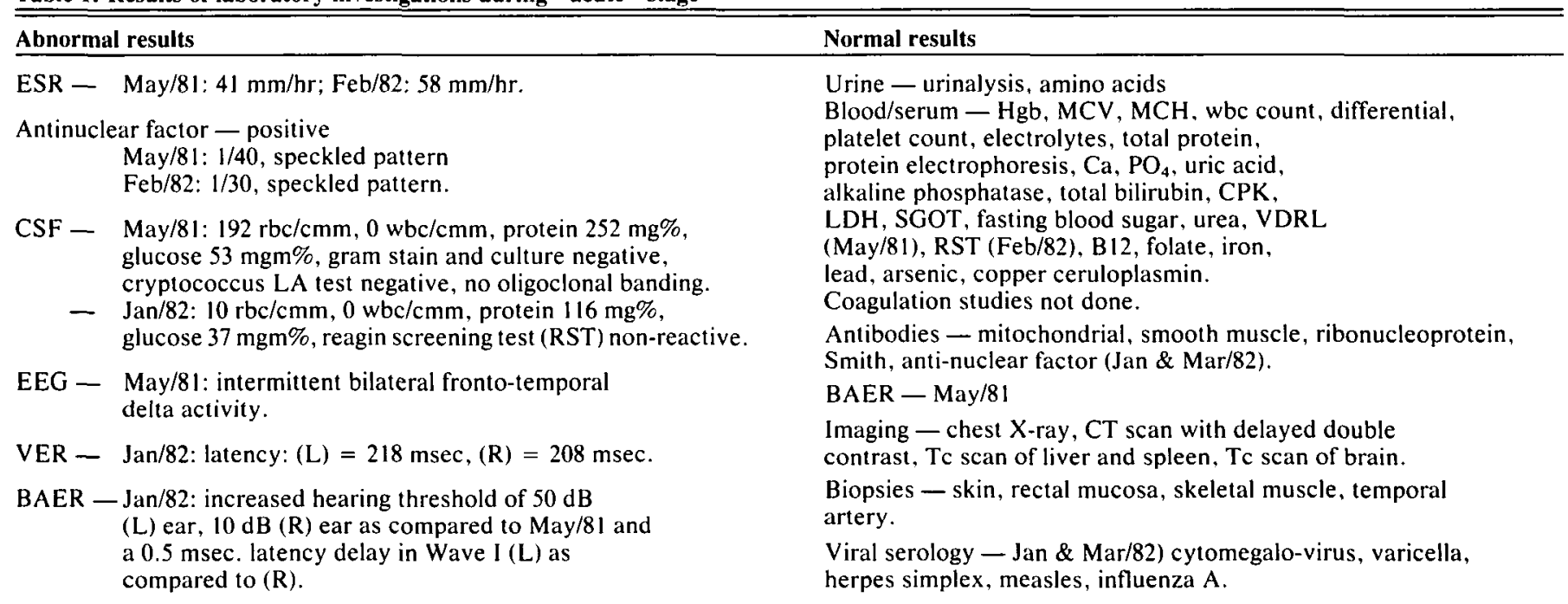

Additional investigation: (Jan/87) all normal: T3, T4, TSH, ESR, prothrombin time, PTT, thrombin time, bleeding time, Factor XII, antithrombin III activity, fibrinogen time, anti-SS-A\&B.

Investigations not done: cerebral angiography, cerebral biopsy, MRI of brain, ultrasound of heart and neck vessels. 


\begin{tabular}{|c|c|c|}
\hline & MacFadyen et al & Previous cases \\
\hline Sex & female & all female \\
\hline Age & 31 & $21 \cdot 40$ \\
\hline Initial symptoms & numbness of extremities, dysarthria & $\begin{array}{l}\text { personality or mental status changes }(5 / 6) \text {, hearing loss }(2 / 6) \text {, } \\
\text { fever, headache, ataxia and vomiting }(1 / 6) \text {, dysarthria }(1 / 6)\end{array}$ \\
\hline Subsequent symptoms & $\begin{array}{l}\text { (L) scotoma, personality change, } \\
\text { memory loss, tinnitus, bilateral hearing } \\
\text { loss, further (L) visual loss }\end{array}$ & $\begin{array}{l}\text { ataxia }(3 / 6) \text {, dementia }(1 / 6) \text {, memory loss }(3 / 6) \text {, obtundation }(1 / 6) \text {, } \\
\text { mood/personality changes }(1 / 6) \text {, dysarthria }(2 / 6) \text {, hearing loss }(3 / 6) \text {, } \\
\text { visual loss bilateral }(2 / 6) \text {, unilateral }(2 / 6)\end{array}$ \\
\hline Neurologic findings & $\begin{array}{l}\text { dysarthria, }(L) \text { VIth palsy, ataxia, } \\
\text { hyper-reflexia, bilateral Babinski, } \\
\text { normal sensation }\end{array}$ & $\begin{array}{l}\text { gaze palsy }(1 / 6) \text {, ataxia }(3 / 6) \text {, hyper-reflexia or Babinski }(5 / 6) \text {, } \\
\text { grasp reflex }(2 / 6) \text {, nystagmus }(2 / 6) \text {, normal sensation }(3 / 3)\end{array}$ \\
\hline Cerebral/mental changes & personality change, memory loss & $\begin{array}{l}\text { amnesia or disorientation (1/6), paranoia }(2 / 6) \text {, personality } \\
\text { change }(2 / 6) \text {, seizures and obtundation }(1 / 6)\end{array}$ \\
\hline $\begin{array}{l}\text { Visual findings } \\
- \text { visual acuity }\end{array}$ & $<20 / 30$ unilateral & $<20 / 30$ unilaterally $(1 / 6),<20 / 30$ bilaterally $(1 / 6)$ \\
\hline - retina & $\begin{array}{l}\text { focal retinal infarcts, small hemorrhages, } \\
\text { arterial occlusion, arterial narrowing, } \\
\text { perivascular sheathing }\end{array}$ & $\begin{array}{l}\text { retinal infarcts }(6 / 6) \text {, retinal hemorrhages }(1 / 6) \text {, inflammatory } \\
\text { changes including vitreous, uvea }(0 / 6) \text {, arterial narrowing }(6 / 6) \text {, } \\
\text { arterial occlusion }(6 / 6)\end{array}$ \\
\hline Audiometric findings & $\begin{array}{l}\text { bilateral low-frequency neurosensory } \\
\text { loss: asymmetric } \\
\text { BAER: unilateral abnormality }\end{array}$ & $\begin{array}{l}\text { bilateral asymmetric neurosensory loss }(5 / 6) \text {; hearing loss but no } \\
\text { audiometry }(1 / 6) \\
\text { normal }(2 / 6) \text {, unknown }(4 / 6)\end{array}$ \\
\hline EEG & $\begin{array}{l}\text { intermittent bilateral frontotemporal } \\
\text { delta }\end{array}$ & generalized dysrhythmia or bilateral slow activity $(5 / 6)$, normal $(1 / 6)$ \\
\hline CT scan & normal & normal $(6 / 6)$ \\
\hline Brain MRI & not done & $\begin{array}{l}\text { "several small discrete foci of abnormally high signal intensity } \\
\text { throughout the supratentorial white matter" (1/6) }\end{array}$ \\
\hline $\begin{array}{l}\text { Abnormal laboratory } \\
\text { findings }\end{array}$ & $\begin{array}{l}\text { elevated CSF protein, elevated ESR, } \\
+ \text { ANF }(1 / 30 \& 1 / 40)\end{array}$ & $\begin{array}{l}\text { CSF: elevated protein }(5 / 6), 12-17 \text { lymphocytes }(2 / 6) \text {; } \\
\text { elevated ESR }(1 / 6)\end{array}$ \\
\hline Brain biopsy & not done & microinfarcts in grey matter $(1 / 6)$, "healed angiitis" $(1 / 6)$ \\
\hline Echocardiography & not done & normal $(4 / 6)$ \\
\hline Treatment & prednisone & $\begin{array}{l}\text { prednisone/hydrocortisone/dexamethasone }(6 / 6) \text {, } \\
\text { cyclophosphamide }(3 / 6)\end{array}$ \\
\hline Follow-up & $\begin{array}{l}\text { hyper-reflexia, visual field defects, } \\
\text { asymmetric hearing loss; unchanged } \\
\text { after six years }\end{array}$ & $\begin{array}{l}\text { moderate to mild dementia }(4 / 6) \text {, hyper-reflexia }(4 / 6) \text {, hearing and } \\
\text { visual loss }(4 / 6: 2 / 6 \text { unknown) }\end{array}$ \\
\hline
\end{tabular}

\section{REFERENCES}

1. Susac JO, Hardman JM, Selhorst JB. Microangiopathy of the brain and retina. Neurology 1979; 29: 313-316.

2. Coppeto JR, Currie JN, Monteiro MLR, et al. A syndrome of arterial-occlusive retinopathy and encephalopathy. Am J Ophthalmol 1984; 98: 189-202.

3. Monteiro MLR, Swanson RA, Coppeto JR, et al. A microangiopathic syndrome of encephalopathy, hearing loss and retinal arteriolar occlusions. Neurology 1985; 35: 1113-1121.

4. Verriest G, VanLaethem J. Uvijls A. A new assessment of the normal ranges of the Farnsworth Munsell 100-Hue test scores. Am J Ophthalmol 1982; 93; 635-642.
5. Pfaffenbach DD, Hollenhorst RW. Microangiopathy of the retinal arterioles. JAMA 1973; 225: 480-483.

6. Weidauer $\mathrm{H}$, Tenner A. Bilateral acute hearing loss with a transient occlusion of the retinal artery on both sides. Z Larngol Rhinol Otol 1973; 52: 121-128.

7. Tan EM, Cohen AS, Fries JF, et al. The 1982 revised criteria for the classification of systemic lupus erythematosus. Arthritis \& Rheumatism 1982; 25: 1271-1277.

8. Feinstein DI. Lupus anticoagulant, thrombosis and fetal loss. NEJM 1985; 313: 1348-1350. 